\title{
A New Strain of Streptomyces Causing Common Scab in Potato
}

\author{
Leslie A. Wanner, USDA-ARS Vegetable Laboratory, 10300 Baltimore Ave., Beltsville, MD 20705
}

\begin{abstract}
Wanner, L. A. 2007. A new strain of Streptomyces causing common scab in potato. Plant Dis. 91:352-359.

Common scab is a serious disease of potatoes (Solanum tuberosum) and other root and tuber crops, affecting the quality and market value of these crops. The disease is caused by grampositive soil bacteria in the genus Streptomyces. A new common scab-causing streptomycete was isolated from scabby potatoes originating in southeastern Idaho. Research has supported a model of horizontal transfer of pathogenicity determinants among streptomycetes, and the new strain has hallmarks of the recently characterized Streptomyces pathogenicity island (PAI); it has genes encoding the synthetase for the pathogenicity determinant thaxtomin and for a second pathogenicity factor, tomatinase, although it lacks a third gene characteristic of the Streptomyces PAI, the necl gene. The new strain has a unique 16s rDNA gene sequence closely related to those of other pathogenic Streptomyces species. This 16s rDNA sequence was also found in isolates lacking a PAI, suggesting that the new pathogenic strain arose by horizontal transfer of a PAI into a saprophytic streptomycete. Isolates of the new strain are pathogenic on radish and potato, and are more virulent than the $S$. scabies type strain. In addition to scab lesions on potato tubers, lesions were also seen on underground stems and stolons. This new strain represents additional complexity in the pathogenic strains causing plant disease in the United States.
\end{abstract}

Additional keywords: Streptomyces scabiei, Streptomyces scabies

Common scab is a serious disease of potatoes (Solanum tuberosum) and other root and tuber crops, affecting the quality and thus the market value of these crops. In a recent survey of Canadian potato growers, $82 \%$ reported their crops were affected by common scab, with loss estimates averaging about $\$ 100.00$ per hectare (14). Other host plants for common scab include radish, carrot, beet, parsnip, and turnip $(10,22)$. Symptoms of common scab include various types of raised, pitted, or superficial lesions on tubers that are usually darker or different in color than healthy tuber skin. The disease is caused by soil-inhabiting gram-positive bacteria in the genus Streptomyces. Although this genus is ubiquitous in soil, most streptomycetes are not plant pathogens. It has been estimated that a few percent of soil streptomycetes are pathogenic to plants (22).

Streptomyces scabies (synonym, S. scabiei) is the best-described species of scab-

Corresponding author: L. A. Wanner

E-mail: wannerl@ba.ars.usda.gov

GenBank accession numbers: DQ341443, DQ861639.

Accepted for publication 11 October 2006.

doi:10.1094/PDIS-91-4-0352

This article is in the public domain and not copyrightable. It may be freely reprinted with customary crediting of the source. The American Phytopathological Society, 2007. causing streptomycete; it has recently been divided into several morphologically similar but genetically distinct species (2). At present, streptomycetes causing common scab in potato are classified into at least 10 different species $(2,17,22,24)$, and at least three additional species cause netted scab in Europe or russet scab in North America $(2,3,8,29)$. Another species causes scab on sweet potatoes (7).

Common scab occurs worldwide, but the incidence varies from region to region, year to year, and field to field. Growers report that potato common scab has become more severe, and occurs on potato cultivars that have previously been considered relatively resistant. There has been little investigation of possible reasons for this. Changes in incidence from year to year could be the result of differences in pathogen load in the soil as a consequence of weather-related changes in soil ecology leading to altered populations of pathogenic streptomycetes and/or competitors. Another possibility is the appearance of new scab-causing species or strains better adapted to new conditions or potato cultivars, or that have acquired different virulence characteristics.

A mechanism for spread of plant pathogenicity determinants in soil streptomycetes by horizontal transfer of a large chromosomal region containing genes for pathogenicity has recently been proposed $(6,16)$. Phylogenetically diverse soil streptomycetes have thus presumably acquired a set of genes for pathogenicity harbored in a pathogenicity island (PAI) to become plant pathogens. A conserved gene region with the characteristics of a PAI has been demonstrated in S. scabies, S. acidiscabies, and $S$. turgidiscabies $(5,6,13,16)$.

During the course of a recent survey of plant-pathogenic streptomycetes isolated from common scab lesions on potatoes from several locations in the United States (31), a new strain of streptomycete was isolated from scabby potatoes originating in southeastern Idaho. The objective of the current study was to examine morphological and molecular characteristics, pathogenicity, and the phylogenetic relationship of this new plant-pathogenic streptomycete.

\section{MATERIALS AND METHODS}

Bacterial isolates. Five Streptomyces isolates obtained from scabby potatoes from southeastern Idaho are described here; two of these isolates were previously partially characterized (31). The procedure used for isolating streptomycetes from scabby potato tubers was described previously (31). Isolates were compared with the S. scabies type strain, ATCC 49173 , obtained from the American Type Culture Collection in Manassas, VA. Although variation in virulence exists among Streptomyces field isolates and ATCC 49173 is not the most virulent isolate described in the literature (31), it was used because it is the type strain of S. scabies, and as such, it is both available to all and often used as a standard of comparison. Yeast-malt extract (YME) or YME-agar (28) was used for routine culture of Streptomyces isolates and strains. Strains were maintained as spore suspensions in $20 \%$ glycerol at $-80^{\circ} \mathrm{C}$, and/or as agar plugs cut from YME plates of streptomycetes in active growth and stored at $-80^{\circ} \mathrm{C}$.

Pathogenicity assays. Inoculum was prepared as described (31) with minor modifications. In short, $50 \mathrm{ml}$ of YME in a 250-ml Erlenmeyer flask was inoculated with $4 \times 10^{6}$ Streptomyces spores harvested in water from a 2- to 3-week-old YME plate. Cultures were grown for 3 days, with shaking, at $28^{\circ} \mathrm{C}$. Cells were pelleted by centrifugation and resuspended in one-third the original volume of sterile distilled water. Five milliliters of this resuspended 3-day culture and $50 \mathrm{ml}$ of sterile $2 \times$ Say's solution (40 g sucrose, $2.4 \mathrm{~g}$ asparagine, $1.2 \mathrm{~g} \mathrm{~K}_{2} \mathrm{HPO}_{4}, 20 \mathrm{~g}$ yeast extract in 1 liter of sterile distilled water) were added to a bag containing $300 \mathrm{~cm}^{3}$ of sterile vermiculite. Inoculated vermiculite was incubated for 14 days at $28^{\circ} \mathrm{C}$, and was mixed by shaking the bags every other 
day during incubation. After 14 days, a ca. $1 \mathrm{~cm}^{3}$ sample of the vermiculite culture was removed and shaken in $10 \mathrm{ml}$ of sterile distilled water. Quadruplicate 10- $\mu \mathrm{l}$ dilutions $\left(10^{-2}, 10^{-3}, 10^{-4}, 10^{-5}\right)$ were plated on YME agar. Plates were incubated at $28^{\circ} \mathrm{C}$ for 2 days, and colonies were counted to ensure that only Streptomyces was visible in the inoculum, and to estimate inoculum concentrations.

For both potato and radish pathogenicity testing, $15-\mathrm{cm}$ pots were partly filled with $600 \mathrm{~cm}^{3}$ of a 50:50 mixture of sterile sand:potting soil (Jiffy Mix Plus). Vermiculite inoculum $\left(300 \mathrm{~cm}^{3}\right)$ containing 1 to $10 \times 10^{10} \mathrm{CFU}$ of Streptomyces was added to $2,700 \mathrm{~cm}^{3}$ of 50:50 sterile sand:soil and mixed thoroughly. Inoculumcontaining mixture $\left(1,200 \mathrm{~cm}^{3}\right)$ was overlaid in each pot. Potato tubers were surface-sterilized for $2 \mathrm{~min}$ in $1.5 \%$ bleach $/ 0.5 \%$ soap to eliminate streptomycetes other than the inoculated Streptomyces isolate, and rinsed in sterile distilled water before seed pieces were planted directly in the inoculum-containing layer. Potato cultivars used were Superior (moderately resistant to common scab) and Green Mountain (susceptible to common scab) $(9,12)$. Certified seed potatoes of cultivars Superior and Green Mountain were obtained from Jewel Brothers (Monticello, ME), Cleaves Farms (Sangerville, $\mathrm{ME}$ ), and Maine Farmers Exchange (Presque Isle, ME). Sterilized radish seeds, cultivar Cherriette F1 (Johnny's Selected Seeds, Albion ME), were planted 9 to 10 per pot, as described (31).

Potatoes and radishes were grown in Conviron growth chambers at $24^{\circ} \mathrm{C}$ with a 14-h photoperiod, $200 \mu$ moles $\mathrm{m}^{-2} \mathrm{~s}^{-1}$ light provided by Philips natural daylight fluorescent lamps. Plants were watered with 100 to $200 \mathrm{ml}$ per pot every 2 to 3 days. Potatoes were harvested and scored for scab after 16 weeks. Three replicate pots per potato cultivar per isolate were included in each experiment, and two of the isolates were tested in at least two independent experiments. Radishes were harvested after four and a half weeks. Three replicate pots were included for each isolate tested. Two isolates were tested twice in independent experiments in radish, and the other three isolates were each tested once.

Scab lesion ratings. Scab lesions were rated on all scorable potato tubers (larger than $0.5 \mathrm{~cm}$ in diameter) after 4 months of growth. Potatoes were scored for severity of scab lesions and percentage of area covered by lesions. The lesion severity scale used was: $0=$ no lesions; $1=$ superficial lesions $<10 \mathrm{~mm}$ in diameter; $2=$ superficial lesions $>10 \mathrm{~mm}$ in diameter; $3=$ raised lesions $<10 \mathrm{~mm}$ in diameter; $4=$ raised lesions $>10 \mathrm{~mm}$ in diameter; $5=$ pitted lesions. The final disease rating assigned was on a scale of 0 to 500, which was calculated by multiplying the average lesion severity of all scorable tubers in a pot by the average percent area covered by lesions. Rating of scab lesions on radishes on a 0 to 5 scale was as described (31).

Molecular genetic analysis. For DNA isolation, Streptomyces cultures were grown at $28^{\circ} \mathrm{C}$ for 3 days in YME, and cells were pelleted to obtain ca. 100-mg aliquots which were stored frozen at $-20^{\circ} \mathrm{C}$ until use. Alternatively, plugs were taken from 2- to 3-week-old YME plates of a Streptomyces isolate using a sterile no. 2 cork borer. DNA was isolated from frozen cells or from two to four agar plugs using a Bio101 FAST DNA kit (sphere plus garnet beads and CLS-Y lysing solution) and a QBiogene Fast Prep machine (settings: speed 5.0, time $25 \mathrm{~s}$ ). DNA was eluted from columns in $2 \times 50 \mu \mathrm{l}$ of $10 \mathrm{mM}$ Tris$\mathrm{HCl}, \mathrm{pH}$ 9.0/0.2 mM EDTA. Suitability of DNA preparations for polymerase chain reaction (PCR) amplification was verified by PCR amplification of 16S rRNA genes using the primer pair $16 \mathrm{~s}-1 \mathrm{~F}$ and $16 \mathrm{~s} 455-$ 435 (Table 1). Primers used to uniquely identify plant-pathogenic Streptomyces species are listed in Table 1. All speciesspecific primer combinations were tested with template DNA from: Streptomyces $\mathrm{sp}$. ATCC 10246 (not plant pathogenic), $S$. scabies ATCC 49173, S. scabiei ATCC 33281, S. europaeiscabiei ATCC 33282, S. acidiscabies ATCC 49003, S. turgidiscabies ATCC 700248, S. aureofaciens ATCC 700526, a plant-pathogenic Streptomyces isolate with the 16s rRNA sequence of $S$. stelliscabiei (NY02-3C), and ID03-2B, a nonpathogenic isolate that has 16s rRNA sequence in the variable regions identical to $S$. bottropensis.

Additional analysis of the presence of genes characteristic of the Streptomyces turgidiscabies PAI as described by Kers et al. (16) was carried out by PCR, using primers specific to the thaxtomin Athaxtomin B operon ( $t x t A B)$, a tomatinaselike gene (tomA), and the necl gene (Table 1). Primers for the necl gene were previously described (5). PCR primers were purchased from Integrated DNA Technologies (Coralville, IA). PCR reactions were carried out in $50 \mu \mathrm{l}$ containing $10 \mathrm{mM}$ Tris- $\mathrm{HCl}(\mathrm{pH} 9.0), 50 \mathrm{mM} \mathrm{KCl}, 0.1 \%$

Table 1. Polymerase chain reaction (PCR) primers and conditions used

\begin{tabular}{|c|c|c|c|c|c|}
\hline Gene & Primers & $\begin{array}{c}\text { Annealing } \\
\text { temperature } \\
\left({ }^{\circ} \mathbf{C}\right)\end{array}$ & $\begin{array}{c}\mathbf{M g C l}_{2} \\
\text { concentration } \\
(\mathbf{m M})\end{array}$ & $\begin{array}{l}\text { Product size } \\
\quad \text { (bp) }\end{array}$ & Reference \\
\hline $16 \mathrm{~S}$ rDNA & $\begin{array}{l}\text { 16S-1F: 5'-CATTCACGGAGAGTTTGATCC-3' } \\
\text { 16S 455-435: 5'-ACTTTCGCTTCTTCCCTGCT-3' }\end{array}$ & 55 & 1.5 & 458 & 6,32 \\
\hline necl & $\begin{array}{l}\text { Nf: } 5^{\prime} \text {-ATGAGCGCGAACGGAAGCCCCGGA-3' } \\
\text { Nr: 5'-GCAGGTCGTCACGAAGGATCG-3' }\end{array}$ & 60 & 2.0 & 700 & 5 \\
\hline$T x t A B$ & $\begin{array}{l}\text { TxtAB 1: 5'-CCACCAGGACCTGCTCTTC-3' } \\
\text { TxtAB2: 5'-TCGAGTGGACCTCACAGATG-3' }\end{array}$ & 48 & 1.0 & 385 & 32 \\
\hline TomA & $\begin{array}{l}\text { Tom3: 5'-GAGGCGTTGGTGGAGTTCTA-3' } \\
\text { Tom4: 5'-TTGGGGTTGTACTCCTCGTC-3' }\end{array}$ & 55 & 1.5 & 392 & 32 \\
\hline \multirow[t]{3}{*}{ Species-specific $16 \mathrm{~s}$} & $\begin{array}{l}\text { ASE3: 5'-AACGGCCAGAGATGGTCGC-3' } \\
\text { Scab2m: 5'-TTCGACAGCTCCCTCCCTTAC-3' }\end{array}$ & 62 & 1.0 & 474 & This work \\
\hline & $\begin{array}{l}\text { ASE3: (above) } \\
\text { Aci2: 5'-CGACAGCTCCCTCCCACAAG-3' }\end{array}$ & 62 & 1.0 & 472 & This work \\
\hline & $\begin{array}{l}\text { Aci1: 5'-TCACTCCTGCCTGCATGGGCG-3' } \\
\text { Aci2: (above) }\end{array}$ & 60 & 1.5 & 1,278 & This work \\
\hline Sequencing primers & $\begin{array}{l}\text { 16s-1F (see above) } \\
\text { 16s 455-435: 5'-ACTTTCGCTTCTTCCCTGCT-3' } \\
\text { 16s-3F: 5'CTCTGGGCCGATACTGACG-3' } \\
\text { 16s-2R: 5'CGTTTACGGCGTGGACTACC-3' } \\
\text { 16s 873-893: 5'CCGCAAGGCTAAAACTCAAA-3' } \\
\text { 16s 1346-1366: 5'-ATTGCTGCGGTGAATACGTT-3' } \\
\text { 16s 1366-1346: 5'AACGTATTCACCGCAGCAAT-3' } \\
\text { 16s-1R: 5'-AGAAAGGAGGTGATCCAGCC-3' }\end{array}$ & 55 & & & $\begin{array}{c}6 \\
32 \\
6 \\
6 \\
32 \\
32 \\
32 \\
6\end{array}$ \\
\hline
\end{tabular}


Triton X-100, 1.0-2.0 mM MgCl $2,200 \mu \mathrm{M}$ each dNTP, 25 pmol each primer, $2.5 \mathrm{U}$ Taq DNA polymerase (Promega Corp.), 2$25 \mathrm{ng}$ DNA template $(1 \mu \mathrm{l}$ of a 1:9 dilution), and MilliQ water. Amplification was carried out in a Perkin-Elmer Thermal Cycler 480 programmed for one initial denaturation step at $95^{\circ} \mathrm{C}$ for $3 \mathrm{~min}$, followed by 40 cycles of denaturing at $95^{\circ} \mathrm{C}$ for $20 \mathrm{~s}$, annealing for $30 \mathrm{~s}$, and extension at $72^{\circ} \mathrm{C}$ for $2 \mathrm{~min}$, and ending with a $4^{\circ} \mathrm{C}$ hold. Concentration of $\mathrm{MgCl}_{2}$ and annealing temperature were optimized for each primer pair. Sequences of PCR primers, annealing temperatures, and $\mathrm{MgCl}_{2}$ concentrations used in routine amplifications, and expected product sizes are specified in Table 1. Amplified DNA fragments were separated on $1.5 \%$ agarose gels and stained with ethidium bromide. PCR amplification experiments were repeated at least twice with at least two independently cultured and isolated DNA template preparations for each Streptomyces isolate.

Cloning and sequencing of the 16s rRNA gene. The 16s rRNA gene was amplified from DNA of isolates ID01-12c and ID01-6.2a by PCR using primers 16s-1F and 16s-1R (6). The 1,500-bp PCR product was excised and eluted from an agarose gel using a Zymoclean Gel DNA Recovery Kit (Zymo Research). DNA was cloned into Promega pGEM-T Easy. Six white colonies were picked for each, and DNA was prepared using an alkaline lysis quick prep procedure (27). Clones verified to contain the correct-sized insert were sequenced using the dideoxy-chain termination method and dye terminator labeling on an ABI Prism 310 Gene Analyzer at the USDA-ARS Floral and Nursery Crops Laboratory, or an ABI 4300 by Macrogene, Inc. (Seoul, Korea). Primers used are listed in Table 1, and included: $\mathrm{T} 7$ promoter primer, SP6 promoter primer, $16 \mathrm{~s}-1 \mathrm{~F}, 16 \mathrm{~s}$ 455-435, 16s-3F, 16s-2R, 16s 893-873, 16s 1366-1346, 16s 1646-1366, and 16s-1R. Sequences were assembled using the Seqman subprogram of DNA Star, version 4.05. Complete nucleotide sequences were obtained for the 16s rRNA gene for two isolates, and are available from GenBank (accession numbers DQ341443 [ID01-12c] and DQ861639 [ID01-6.2a]).

\section{RESULTS}

During a previous study of variation in streptomycetes isolated from scabby potatoes from several locations in the United States, a unique group of isolates was identified from southeastern Idaho (31). The isolates came from different years, field locations, potato cultivars, and types of scab lesions, but shared morphological characteristics (Table 2). These isolates are morphologically distinct from the type strain of S. scabies, ATCC 49173, producing a reddish-brown substrate mycelium with gray aerial spores and a red-brown diffusible pigment on YME agar. Like $S$. scabies ATCC 49173, they make an inky black diffusible melanoid pigment on PYI agar.

Pathogenicity on potato and on radish. Isolates from this group were pathogenic on radish and potato. At high soil inoculum densities, all five isolates were consistently more virulent than the $S$. scabies type strain ATCC 49173 on radish, as indicated by scab lesion scores, reduced seedling emergence, and reduced longterm plant survival (Table 3). Radish plants were severely stunted or died at high initial inoculum densities, which precluded development of normal radishes and thus common scab.

Pathogenicity and virulence of two of the isolates was examined and compared with that of S. scabies ATCC 49173 on two potato cultivars. Cultivar Superior was more resistant to common scab than Green Mountain; this was evident in both scab lesion scores and in the appearance of tubers (Table 4; Fig. 1). At low initial soil inoculum densities below $4 \times 10^{3} \mathrm{CFU} / \mathrm{cm}^{3}$, few or no symptoms were seen on tubers of either potato cultivar with any of the three Streptomyces strains tested (Fig. 1, top row; Table 4). Coalescing red-brown scab lesions several millimeters deep were seen on Green Mountain tubers formed in soil infested with ATCC 49173 or with two Idaho isolates at $1,000 \times$ higher initial inoculum density of 1 to $5 \times 10^{6} \mathrm{CFU} / \mathrm{cm}^{3}$ soil (Fig. 1, second row left; Table 4). Scab lesions were fewer, isolated, and mostly superficial on less susceptible Superior tubers (Fig. 1, second row right; Table 4).

Table 3. Virulence characteristics of newly described Idaho Streptomyces isolates on radish compared with S. scabiei ${ }^{\mathrm{T}}$ (ATCC 49173)

\begin{tabular}{lcccc}
\hline Isolate & $\begin{array}{c}\text { Initial } \\
\text { inoculum } \\
\text { density }^{\mathbf{a}}\end{array}$ & $\begin{array}{c}\text { Scab } \\
\text { lesion } \\
\text { score }^{\mathbf{b}}\end{array}$ & $\begin{array}{c}\text { Seedling } \\
\text { emergence } \\
(\boldsymbol{\%})^{\mathbf{c}}\end{array}$ & $\begin{array}{c}\text { Plant survival } \\
\text { after 5 weeks } \\
(\boldsymbol{\%})^{\mathbf{c}}\end{array}$ \\
\hline ID01-12c & 7.03 & $\mathrm{DD}^{\mathrm{d}}$ & 15 & 0 \\
& 6.65 & $4.33\left(\mathrm{D}^{\mathrm{e}}\right)$ & 51.8 & 0 \\
ID01-6.2a & 7.47 & $\mathrm{DD}$ & 14 & 4 \\
& 7.06 & $\mathrm{DD}$ & 4 & 0 \\
ID03-1A & 7.49 & $4.0(\mathrm{D})$ & 95 & 14 \\
ID03-2A & 7.06 & $4.1(\mathrm{D})$ & 95 & 36 \\
ID03-3A & 7.0 & $3.5(\mathrm{DD})$ & 90 & 7 \\
S. scabiei type strain ATCC 49173 & $6.75^{\mathrm{f}}$ & $3.48^{\mathrm{f}}$ & $88^{\mathrm{f}}$ & $82^{\mathrm{f}}$ \\
$\quad$ [range] & {$[6.18-7.27]$} & {$[1.78-4.43]$} & {$[63-100]$} & {$[52-100]$} \\
(independent experiments) & $(14)$ & $(14)$ & $(12)$ & $(12)$ \\
\hline
\end{tabular}

${ }^{a}$ Log CFU of Streptomyces isolate or strain per cubic centimeter of soil.

${ }^{\mathrm{b}}$ Severity $\times$ area, $0-5$ scale; scores are averages for 3 pots in an independent experiment $(9$ plants per pot), or for the number of experiments given in parentheses for ATCC 49173.

${ }^{\mathrm{c}}$ Percentages are averages for 3 pots in an independent experiment ( 9 plants per pot), or for the number of experiments given in parentheses for ATCC 49173.

${ }^{\mathrm{d}}$ All plants dead (no radishes to score).

e Many plants dead (few radishes to score).

${ }^{\mathrm{f}}$ Average in multiple independent experiments; the range among independent experiments is shown in brackets, and the number of experiments is given in parentheses.

Table 2. Features of isolates of a new Streptomyces strain from southeastern Idaho compared with S. scabies ${ }^{\mathrm{T}}$ ATCC 49173

\begin{tabular}{|c|c|c|c|c|c|c|}
\hline Isolate & ATCC $49173^{a}$ & ID01-12c & ID01-6.2a & ID03-1A & ID03-2A & ID03-3A \\
\hline $\begin{array}{l}\text { Location and harvest } \\
\text { year of original lesion }\end{array}$ & $\begin{array}{l}\text { New York, } \\
1984\end{array}$ & $\begin{array}{l}\text { Aberdeen, ID, } \\
2001\end{array}$ & $\begin{array}{l}\text { American Falls, ID, } \\
2001\end{array}$ & $\begin{array}{l}\text { Aberdeen, ID } \\
2003\end{array}$ & $\begin{array}{l}\text { Aberdeen, ID, } \\
2003\end{array}$ & $\begin{array}{l}\text { Aberdeen, ID, } \\
2003\end{array}$ \\
\hline Potato cultivar & Katahdin ${ }^{\mathrm{b}}$ & $\begin{array}{l}\text { Not noted (white- } \\
\text { skinned cultivar) }\end{array}$ & Shepody & Defender & $\begin{array}{l}\text { Breeding line KSA } \\
\quad 195-90\end{array}$ & Ranger Russet \\
\hline Lesion appearance & Not noted ${ }^{b}$ & Brown slightly pitted & Deep pitted & Raised lesions & Small pitted lesions & Raised lesions \\
\hline $\begin{array}{l}\text { Substrate mycelium } \\
\text { color }\end{array}$ & Light brown ${ }^{a}$ & Reddish-brown & Reddish-brown & Reddish-brown & Reddish-brown & Reddish-brown \\
\hline Spore color & Gray $^{\mathrm{a}}$ & Gray & Gray & Gray & Gray & Gray \\
\hline $\begin{array}{l}\text { Color diffusible pigment } \\
\text { on YME }\end{array}$ & Orange-brown ${ }^{\mathrm{a}}$ & Reddish-brown & Reddish-brown & Reddish-brown & Reddish-brown & Reddish-brown \\
\hline TxtAB, tomA genes & + & + & + & + & + & + \\
\hline Necl gene & + & - & - & - & - & - \\
\hline
\end{tabular}

${ }^{a}$ Characteristics of S. scabies ATCC 49173 (=RL-34) from (18) or this work.

${ }^{\mathrm{b}}$ In original reference (18). 
The Idaho isolates killed highly scabsusceptible Green Mountain potato plants planted in soil at this inoculum density, and killed Superior at a 10-fold higher inoculum density, similar to the effects seen on radishes (Table 4). S. scabies ATCC 49173 did not kill potato plants at the highest inoculum density tested (Table 4). When underground portions of wilting or dying plants were examined, the underground stems were deeply discolored, dry, and friable throughout (Fig 1, bottom row). These stems ultimately broke at ground level. Coalescing red-brown scab-like lesions were also visible on the underground stems of cultivar Superior grown in soil infested at high initial inoculum density with the Idaho strain (Fig 1, bottom row). Other Streptomyces field isolates tested on potatoes produced symptom severity ranging from that of ATCC 49173 to that of the Idaho strain. Symptoms included lesions or coalescing lesions on underground stems, stolons, and tubers, and were always more severe on the more susceptible cultivar Green Mountain (data not shown).

Molecular markers in the PAI. The Idaho isolates were tested for the presence of genes characteristic of the Streptomyces turgidiscabies PAI as described by Kers et al. (16). Using PCR primers designed to the $\operatorname{txt} A B$ operon encoding the synthetase for the toxin thaxtomin, a product of the expected size was amplified from all five isolates. Additional PCR primers were used to characterize the other "end" of the PAI. PCR analysis of the Idaho isolates revealed that the gene for a tomatinase homolog, tomA, located approximately 300 $\mathrm{kb}$ away from the $t x t A B$ genes in $S$. tur- gidiscabies $(6,16)$, was present in all five isolates. A primer pair amplifying the necl gene, located in the PAI a few kilobases inside the tomA gene in S. turgidiscabies (16), did not produce the expected 700-bp PCR fragment in any of the five Idaho isolates.

Phylogenetic affiliation. There are three short regions of sequence variation in the 16s rRNA gene in plant-pathogenic Streptomyces species described to date (Fig. 2). These are the $\gamma$ variable region between nucleotides 172 and 197, the $\alpha$ variable region between nucleotides 970 and 1012, and a third variable region centered on nucleotide 1435 (numbering according to the $S$. scabies type strain 16 s rRNA gene sequence, GenBank accession number 971124). Based on these sequence variable regions, seven different sets of PCR primers were designed to amplify the 16s rDNA sequence characteristic of described plant-pathogenic Streptomyces species (Fig. 2; 32), including S. scabies, S. europaeiscabiei, S. stelliscabiei, $S$. bottropensis, S. acidiscabies, S. turgidiscabies, and $S$. aureofaciens. Lack of PCR amplification in the Idaho strains with $S$. scabies/S. europaeiscabiei and S. acidiscabies species-specific primers is shown in Figure 3A (lanes 5 through 9). Results with the other species-specific primer pairs are not shown, but no PCR product was obtained when any of these five Idaho isolates was used as DNA template. Therefore, the 16s rRNA gene was cloned and sequenced from two Idaho isolates. The sequence was $99 \%$ identical to the $16 \mathrm{~s}$ rRNA sequences of $S$. scabies, $S$. europaeiscabiei, and $S$. bottropensis, differing only in one or more of three sequence variable regions depicted in Figure 2 and at four other isolated nucleotide positions in the 16s rDNA sequence (data not shown). The Idaho isolates share the sequence of the $\alpha$ variable region (nucleotides 970 to 1012) with S. scabies, S. europaeiscabiei, $S$. acidiscabies, and $S$. diastatochromogenes, but differ from $S$. scabies and $S$. europaeiscabiei in the variable region centered around nucleotide 1435, and from $S$. acidiscabies and $S$. diastatochromogenes in the sequence of the $\gamma$ variable region located between nucleotides 170 and 195 . Use of the PCR primers ASE3 and scab2m followed by PCR primers aci1 and aci2 (Table 1; Fig. 2) separates the Idaho isolates from these four Streptomyces species (Fig. 3B and C). The Idaho isolates thus have a unique combination of $16 \mathrm{~s}$ rDNA variable sequence regions, different from those previously described for pathogenic and nonpathogenic streptomycetes closely related to $S$. scabies.

Use of the Idaho + acidiscabies-specific PCR primer pair ASE3 and aci2 followed by the $S$. acidiscabies-specific primer pair aci1 and aci 2 on a collection of Streptomyces isolates or strains revealed three nonpathogenic isolates sharing this combination of sequences in the $\gamma, \alpha$ and 1435 regions of the 16s rRNA gene (32). The three isolates came from different locations (and years) in Wisconsin, and from eastern Washington.

\section{DISCUSSION}

Earlier research has supported a model of horizontal transfer of pathogenicity determinants among closely related streptomycetes, as well as into distantly related streptomycetes $(6,16,19,23)$, creating new

Table 4. Virulence of newly described Idaho Streptomyces isolates at different initial inoculum densities on two potato cultivars compared with $S$. scabiei ${ }^{\mathrm{T}}$ (ATCC 49173)

\begin{tabular}{|c|c|c|c|c|c|}
\hline \multirow[b]{2}{*}{ Isolate } & \multirow[b]{2}{*}{ Initial inoculum $^{a}$} & \multicolumn{2}{|r|}{ Superior } & \multicolumn{2}{|c|}{ Green Mountain } \\
\hline & & Scab score $^{b}$ & Experimental details ${ }^{c}$ & Scab score $^{b}$ & Experimental details ${ }^{c}$ \\
\hline ID01-12c & $\begin{array}{c}7-7.5 \\
5.6 \\
4.6 \\
3.6 \\
2.6\end{array}$ & $\begin{array}{c}\mathrm{DD}^{\mathrm{d}} \\
50 \pm 30 \\
4.4 \pm 3.6^{\mathrm{e}} \\
13.2 \pm 12.9^{\mathrm{e}} \\
0.3 \pm 0.3^{\mathrm{e}}\end{array}$ & $\begin{array}{l}2 \text { expt ( } 4 \text { pots, } 0 \text { tubers) } \\
1 \text { expt ( } 2 \text { pots, } 7 \text { tubers) } \\
1 \text { expt ( } 3 \text { pots, } 15 \text { tubers) } \\
1 \text { expt ( } 3 \text { pots, } 11 \text { tubers) } \\
1 \text { expt ( } 3 \text { pots, } 7 \text { tubers) }\end{array}$ & $\begin{array}{c}\mathrm{DD}^{\mathrm{d}} \\
462 \\
131 \pm 89 \\
11.3 \pm 11.8^{\mathrm{e}} \\
5.3^{\mathrm{e}}\end{array}$ & $\begin{array}{l}2 \text { expt ( } 4 \text { pots, } 0 \text { tubers }) \\
1 \text { expt ( } 3 \text { pots, } 7 \text { tubers }) \\
1 \text { expt ( } 3 \text { pots, } 7 \text { tubers }) \\
1 \text { expt ( } 3 \text { pots, } 2 \text { tubers }) \\
1 \text { expt ( } 3 \text { pots, } 2 \text { tubers })\end{array}$ \\
\hline ID01-6.2a & $\begin{array}{c}6.3-6.6 \\
5.6 \\
4.6 \\
3.6 \\
2.6\end{array}$ & $\begin{array}{l}46 \pm 37 \\
95 \pm 49 \\
34 \pm 3 \\
21 \pm 32 \\
0.8 \pm 1.3^{\mathrm{e}}\end{array}$ & $\begin{array}{l}2 \text { expt ( } 6 \text { pots, } 19 \text { tubers) } \\
1 \text { expt ( } 3 \text { pots, } 7 \text { tubers) } \\
1 \text { expt ( } 3 \text { pots, } 10 \text { tubers) } \\
1 \text { expt ( } 3 \text { pots, } 10 \text { tubers) } \\
1 \text { expt ( } 3 \text { pots, } 8 \text { tubers })\end{array}$ & $\begin{array}{c}\mathrm{DD}^{\mathrm{d}} \\
157 \\
271 \pm 173 \\
16 \pm 17.5 \\
8.7 \pm 9.0^{\mathrm{e}}\end{array}$ & $\begin{array}{l}2 \text { expt ( } 5 \text { pots, } 0 \text { tubers }) \\
1 \text { expt ( } 3 \text { pots, } 6 \text { tubers }) \\
1 \text { expt ( } 3 \text { pots, } 7 \text { tubers }) \\
1 \text { expt ( } 3 \text { pots, } 4 \text { tubers }) \\
1 \text { expt ( } 3 \text { pots, } 5 \text { tubers })\end{array}$ \\
\hline ATCC 49173 & $\begin{array}{c}7-7.3 \\
6.7 \\
6.1-6.2 \\
5.9 \\
5.6 \\
4.6 \\
3.6 \\
2.6\end{array}$ & $\begin{array}{c}90.8 \pm 35.5 \\
80 \pm 32 \\
89.3 \pm 69.2 \\
67 \pm 111 \\
22 \pm 4.4 \\
35 \pm 45 \\
12.7 \pm 17 \\
5.0 \pm 6.2^{\mathrm{e}}\end{array}$ & $\begin{array}{l}3 \text { expt ( } 7 \text { pots, } 30 \text { tubers) } \\
1 \text { expt ( } 3 \text { pots, } 11 \text { tubers) } \\
3 \text { expt ( } 7 \text { pots, } 24 \text { tubers) } \\
1 \text { expt ( } 3 \text { pots, } 8 \text { tubers }) \\
1 \text { expt ( } 2 \text { pots, } 5 \text { tubers }) \\
1 \text { expt ( } 2 \text { pots, } 6 \text { tubers }) \\
1 \text { expt ( } 2 \text { pots, } 9 \text { tubers }) \\
1 \text { expt }(2 \text { pots, } 5 \text { tubers })\end{array}$ & $\begin{array}{c}292 \pm 128 \\
293 \pm 15.9 \\
202 \pm 62 \\
200 \\
\mathrm{~N}^{\mathrm{f}} \\
90 \\
24 \\
3.1^{\mathrm{e}}\end{array}$ & $\begin{array}{l}1 \text { expt ( } 3 \text { pots, } 25 \text { tubers) } \\
1 \text { expt ( } 3 \text { pots, } 12 \text { tubers) } \\
2 \text { expt ( } 5 \text { pots, } 18 \text { tubers) } \\
2 \text { expt ( } 3 \text { pots, } 3 \text { tubers }) \\
1 \text { expt ( } 2 \text { pots, } 0 \text { tubers) } \\
1 \text { expt ( } 2 \text { pots, } 1 \text { tuber }) \\
1 \text { expt ( } 2 \text { pots, } 2 \text { tubers }) \\
1 \text { expt ( } 2 \text { pots, } 2 \text { tubers })\end{array}$ \\
\hline
\end{tabular}

\footnotetext{
${ }^{\text {a }}$ Initial inoculum density, $\log$ CFU per $\mathrm{cm}^{3}$ of soil.

b Score $=$ lesion severity $\times$ area, 0-500 scale \pm standard deviation of the mean.

c Number of independent experiments (total number of pots, scorable tubers in all experiments).

d Plants dead (no tubers to score).

e Not different from noninoculated controls.

${ }^{f} \mathrm{~N}=$ no tubers, plants healthy.
} 
plant-pathogenic strains or species. Evidence is presented here of acquisition of pathogenicity in a new strain of Streptomyces in Idaho. The recipient strain appears to be closely related to $S$. scabies, S. europaeiscabiei, and other plant-pathogenic streptomycetes as defined by the sequence of the 16s rRNA gene; it is identical to one or more previously described plantpathogenic species in each of three variable sequence regions, but has a unique combination of the three. Identification of Streptomyces isolates from eastern Washington and from Wisconsin with this combination of sequence variable regions in the 16s rRNA gene, but lacking genes characteristic of the PAI, suggests that the origin of this Idaho strain could have been horizontal transfer of the PAI into a naturally occurring nonpathogenic streptomycete.

The Idaho strain shares features of the PAI with other described plant-pathogenic streptomycetes; specifically, it has the $\operatorname{txt} A B$ gene cluster and a tomatinase gene (tomA), which roughly delimit the "ends" of the PAI known from S. turgidiscabies. However, the necl gene, which is located within a 425-kb ASEI restriction endonuclease fragment that also contains both the txtAB gene and the tom $A$ gene in $S$. turgidiscabies (16), is missing in all five isolates from Idaho. Absence of a gene homologous to necl was confirmed in two of the isolates by Southern blotting using the 700-bp necl PCR fragment as a probe (31). Both tomA and necl are present in $S$. scabies, S. acidiscabies, and S. turgidiscabies $(6,16)$. The Idaho isolates thus appear to share a version of the PAI that differs from the PAI in other plant-pathogenic Streptomyces species. Streptomycetes missing the necl gene but retaining plant pathogenicity have previously been reported $(5,17,25,31)$; the presence or absence of the tomatinase gene has not been reported in previous studies. Since tomA is located outside of necl in the PAI of $S$. turgidiscabies, the presence of tomA in the absence of necl is not simply explained by incomplete conjugal transfer of the $S$. tur-

\section{Green Mountain Superior}

\section{ID01-12c}
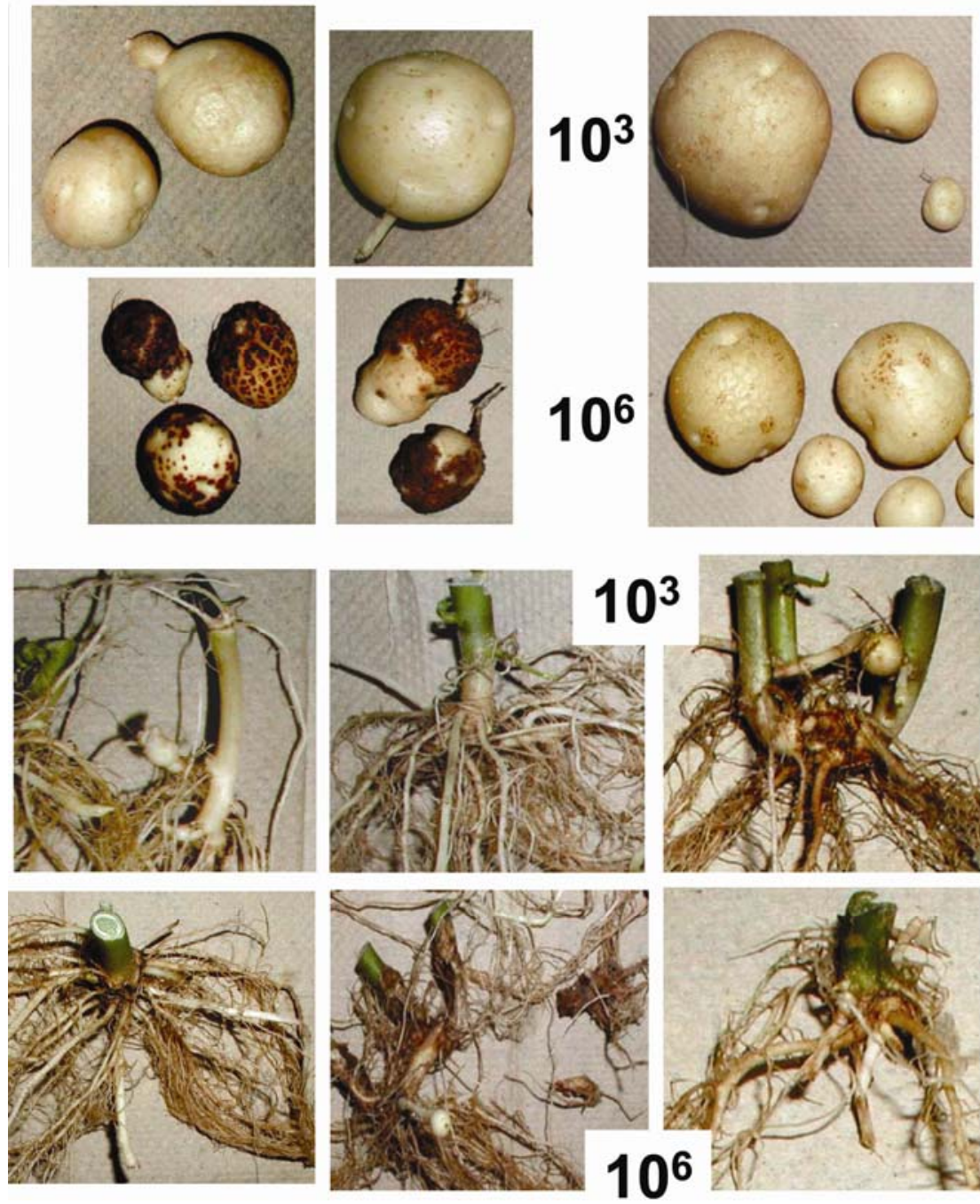
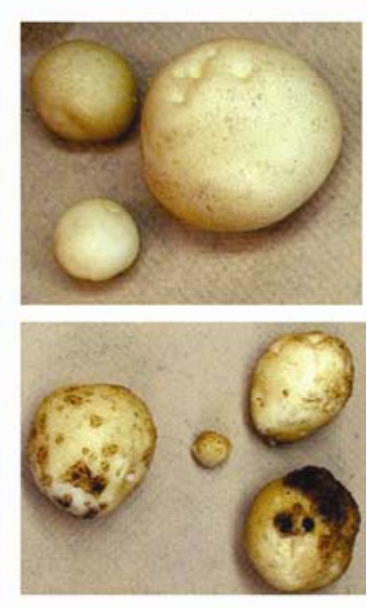

\section{ID01-12c}
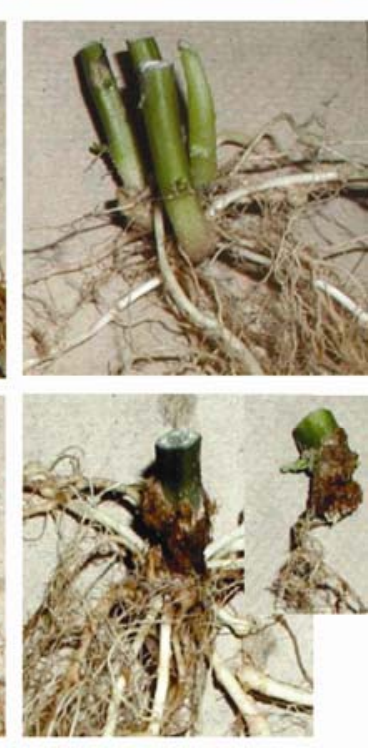

Fig. 1. Symptoms on underground parts of potato plants grown in soil infested with different isolates of plant-pathogenic Streptomyces. Upper left quadrant, tubers of cultivar Green Mountain, grown in soil infested with $4 \times 10^{3}$ (above) or approximately $10^{6}$ (below) CFU Streptomyces per cm ${ }^{3}$ soil. Left panels infested with $S$. scabies ATCC 49173, right panels with ID01-12c. Upper right quadrant, tubers of cultivar Superior, grown in soil infested with $4 \times 10^{3}$ (above) or $10^{6}$ (below) CFU Streptomyces per $\mathrm{cm}^{3}$ soil. Left panels infested with $S$. scabies ATCC 49173, right panels with ID01-12c. Lower left quadrant, underground parts of Green Mountain plants, grown in soil infested with $4 \times 10^{3}$ (above) or $10^{6}$ (below) CFU Streptomyces per cm ${ }^{3}$ soil. Left panels infested with $S$. scabies ATCC 49173, right panels with ID01-12c. Lower right quadrant, as in lower left quadrant, except the cultivar was Superior. 
gidiscabies PAI. Based on morphological characteristics and the unique sequence of the 16s rRNA gene and combination of markers for the PAI, the Idaho strain appears to be a new genetic type of plantpathogenic Streptomyces.

Variation in virulence of individual Streptomyces isolates is well-known $(2,4,17,31)$, although comparative analyses of virulence have often failed to take into account the importance of inoculum density. At sufficient inoculum density, all five Idaho isolates were found to be pathogenic in radishes, and two isolates tested were found to be pathogenic in two potato cultivars. In radishes, the Idaho strain caused seedling lethality at high inoculum densities. Although seedling lethality was not seen at comparable inoculum densities of the $S$. scabies type strain (ATCC 49173), other field isolates of Streptomyces were as aggressive as the Idaho isolates on radish, and some caused stunting of plants and seedling mortality (31). The disease caused by the Idaho isolates affected underground potato tissues in addition to tubers. Necrotic lesions were seen on stolons and the underground main stem of both Superior and Green Mountain. Lesions were superficial on stolons, stems, and tubers of the less susceptible cultivar Superior, but at high inoculum densities, necrosis of the underground stem was so extensive in the more scab-susceptible potato cultivar Green Mountain that it disrupted the vascular tissue, killing the plants. This type of plant damage has not been attributed to Streptomyces in field situations, but many
Streptomyces field isolates do cause symptoms on underground parts of potato plants in addition to tubers, and damage to underground portions of potato and radish plants grown in soil infested with high inoculum densities can result in aboveground symptoms $(31 ;$ L. A. Wanner, unpublished data).

The Idaho strain is clearly an aggressive potato pathogen, but we do not presently know whether the presence or predominance of this strain could be responsible for differences in common scab symptoms or severity observed in regions where it occurs. Differences in common scab symptoms have often been attributed to different Streptomyces species $(1,11,17,23)$, although results from subsequent work suggest there is no significant difference in the

$\gamma$ variable region
scabies (971124)
europaeiscabiei (AJ007423)
bottropensis (D63868)
stelliscabiei (5263074)
diastatochromogenes (971132)
acidiscabies (AB026220)
turgidiscabies (AB026221)
ID01-6.2A
ID01-12C
primer scab1m
primer acidil

$\alpha$ variable region

scabies (971124)

europaeiscabiei (AJ007423)

bottropensis (D63868)

stelliscabiei (5263074)

diastatochromogenes (971132)

acidiscabies (AB026220)

turgidiscabies (AB026221)

ID01-6.2A

ID01-12C

primer ASE3

\section{5 variable region}

scabies (971124)
europaeiscabiei (AJ007423)
bottropensis (D63868)
stelliscabiei (5263074)
diastatochromogenes (971132)
acidiscabies (AB026220)
turgidiscabies (AB026221)
ID01-6.2a
ID01-12c
primer scab2m
primer acidi2

Fig. 2. Variable sequence regions in the 16s rDNA of the new Idaho strain in comparison with other pathogenic Streptomyces species and groups, and the nonpathogenic $S$. diastatochromogenes. Nucleotide numbering is the same as used previously (6), and is based on the $S$. aureofaciens 16 s rDNA sequence. When sequence information was obtained from GenBank, accession numbers follow the Streptomyces species designations in parentheses. Streptomyces species-specific polymerase chain reaction (PCR) primers referred to in the text are indicated. 
pathogenicity of S. scabies, S. acidiscabies, S. turgidiscabies, and S. stelliscabiei $(3,15,20,21)$. Only $S$. europaeiscabiei and $S$. reticuliscabiei have been shown to differ in plant pathogenicity. S. reticuliscabiei causes netted scab on the surface of tubers as well as root symptoms, and both species show differences in plant host range, including differences among potato cultivars $(3,26)$. Experiments are underway to determine whether the Idaho isolates differ in aggressiveness or host range.
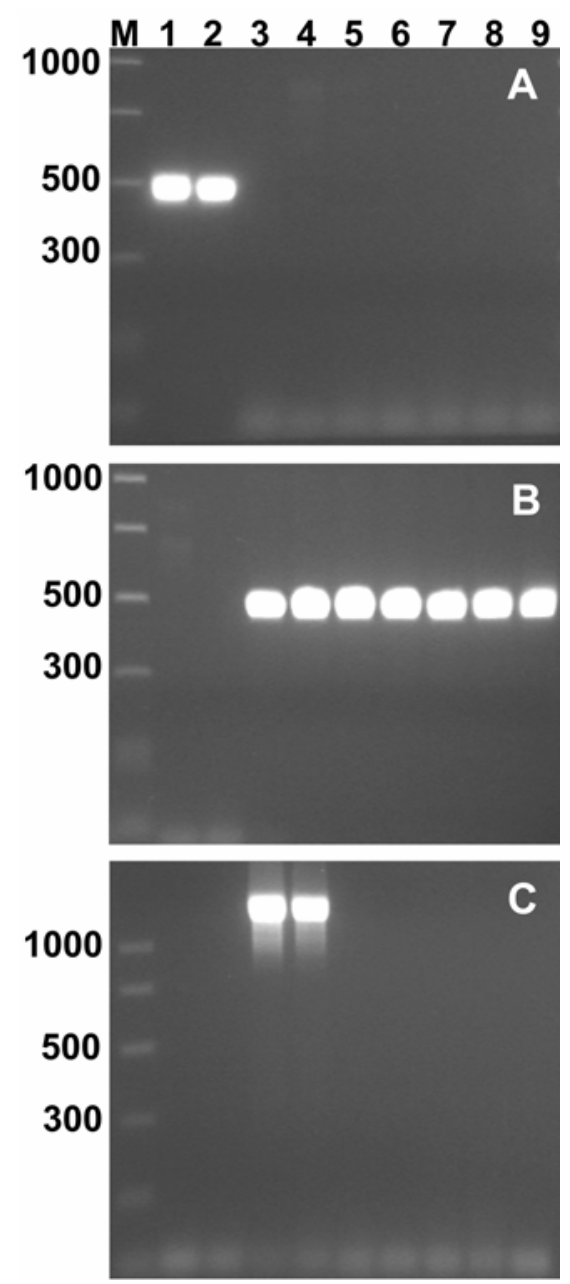

Fig. 3. Unique identification of the Idaho Streptomyces isolates by polymerase chain reaction (PCR) with primers specific to plant-pathogenic Streptomyces species. A, DNA templates from Streptomyces isolates amplified with PCR primers ASE3 and Scab2m, specific for $S$. scabies and S. europaeiscabiei; expected PCR product size, $474 \mathrm{bp}$. B, The same set of DNA templates amplified with PCR primers ASE3 and Aci2, producing a 472-bp fragment from both $S$. acidiscabies and the Idaho isolates. $\mathbf{C}$, The same set of DNA templates amplified with the $S$. acidiscabies-specific primers Aci1 and Aci2, producing a 1,278-bp DNA fragment from $S$. acidiscabies. Lane assignments: M, Promega PCR markers (sizes indicated in bp along left side of gels); 1, S. scabies $^{\mathrm{T}}$ ATCC 49173; 2, isolate ID01-16c (S. europaeiscabiei); 3, S. acidiscabies $^{\text {T }}$ ATCC 49003; 4, isolate ME026987A (S. acidiscabies); 5, isolate ID01-6.2A; 6 , isolate ID01-12c; 7, isolate ID03-1A; 8, isolate ID03-2A; 9, isolate ID03-3A.
In summary, a new plant-pathogenic Streptomyces strain was isolated from scabby potatoes collected in Aberdeen and American Falls, ID, in the 2001 growing season and again in Aberdeen in the 2003 growing season. Although a pathogenic version of this strain has so far been identified only from a small region of southeastern Idaho, streptomycetes having the same 16s rRNA sequence but lacking the hallmarks of a PAI, including the $t x t A B$, necl, and tom $A$ genes, have been identified from eastern Washington, and from two locations and two different years in Wisconsin. It seems likely that an endemic saprophytic Streptomyces species acquired a modified version of the Streptomyces PAI by horizontal transfer from pathogenic streptomycetes to create a new pathogenic species or strain. This new strain adds additional complexity in the pathogenic strains available to cause plant disease in the United States.

\section{ACKNOWLEDGMENTS}

The excellent technical assistance of Marshall Elson is gratefully acknowledged. Thanks to Mike Reinsel and John Hammond of the USDA-ARS/US National Arboretum Floral and Nursery Crops Lab for help with DNA sequencing, and to John Hartung and Jeff Miller for critical reading of the manuscript. Scabby tubers were provided by Jeff Miller (University of Idaho Research and Extension Center, Aberdeen) and Richard Novy (USDA-ARS, Aberdeen).

\section{LITERATURE CITED}

1. Archuleta, J. G., and Easton, G. D. 1981. The cause of deep-pitted scab of potatoes. Am. Potato J. 58:385-392.

2. Bouchek-Mechiche, K., Gardan, L., Normand, P., and Jouan, B. 2000. DNA relatedness among strains of Streptomyces pathogenic to potato in France: Description of three new species, S. europaeiscabiei sp. nov. and $S$. stelliscabiei $\mathrm{sp}$. nov. associated with common scab, and $S$. reticuliscabiei sp. nov. associated with netted scab. Int. J. Syst. Evol. Microbiol. 50:91-99.

3. Bouchek-Mechiche, K., Pasco, C., Andrivon, D., and Jouan, B. 2000. Differences in host range, pathogenicity to potato cultivars and response to soil temperature among Streptomyces species causing common and netted scab in France. Plant Pathol. 49:3-10.

4. Bramwell, P. A., Wiener, P., Akkermans, A. D., and Wellington, E. M. 1998. Phenotypic, genotypic and pathogenic variation among streptomycetes implicated in common scab disease. Lett. Appl. Microbiol. 27:255-260.

5. Bukhalid, R. A., Chung, S. Y., and Loria, R. 1998. necl, a gene conferring a necrogenic phenotype, is conserved in plant-pathogenic Streptomyces spp. and linked to a transposase pseudogene. Mol. Plant-Microbe Interact. 11:960-967.

6. Bukhalid, R. A., Takeuchi, T., Labeda, D., and Loria, R. 2002. Horizontal transfer of the plant virulence gene, necl, and flanking sequences among genetically distinct Streptomyces strains in the diastatochromogenes cluster. Appl. Environ. Microbiol. 68:738-744.

7. Clark, C. A., Chen, A., Ward-Rainey, N., and Pettis, G. S. 1998. Diversity within Streptomyces ipomoeae based on inhibitory interactions, REP-PCR, and plasmid profiles. Phytopathology $88: 1179-1186$.

8. Faucher, E., Otrysko, B., Paradis, E., Hodge, N. C., Stall, R. E., and Beaulieu, C. 1993.
Characterization of streptomycetes causing Russett scab in Quebec. Plant Dis. 77:12171220.

9. Goth, R. W., Haynes, K. G., and Wilson, D. R. 1993. Evaluation and characterization of advanced potato breeding clones for resistance to scab by cluster analysis. Plant Dis. 77:911914.

10. Goyer, C., and Beaulieu, C. 1997. Host range of streptomycete strains causing common scab. Plant Dis. 81:901-904.

11. Goyer, C., Faucher, E., and Beaulieu, C. 1996. Streptomyces caviscabies sp. nov., from deeppitted lesions in potatoes in Québec, Canada Int. J. Syst. Bacteriol. 46:635-639.

12. Haynes, K. G., Goth, R. W., and Young, R. J. 1997. Genotype $\times$ environment interactions for resistance to common scab in tetraploid potato. Crop Sci. 37:1163-1167.

13. Healy, F. G., Wach, M., Krasnoff, S. B., Gibson, D. M., and Loria, R. 2000. The txtAB genes of the plant pathogen Streptomyces acidiscabies encode a peptide synthetase required for phytotoxin thaxtomin A production and pathogenicity. Mol. Microbiol. 38:794804.

14. Hill, J., and Lazarovits, G. 2005. A mail survey of growers to estimate potato common scab prevalence and economic loss in Canada. Can. J. Plant Pathol. 27:46-52.

15. Hiltunen, L. H., Weckman, A., Ylhäinen, A. Rita, H., Richter, E., and Valkonen, J. P. T. 2005. Responses of potato cultivars to the common scab pathogens, Streptomyces scabies and S. turgidiscabies. Ann. Appl. Biol. 146:395-403.

16. Kers, J., Cameron, K., Joshi, M., Bukhalid, R., Morello, J., Wach, M., Gibson, D., and Loria, R. 2005. A large, mobile pathogenicity island confers plant pathogenicity on Streptomyces species. Mol. Microbiol. 55:10251033.

17. Kreuze, J. F., Suomalainen, S., Paulin, L., and Valkonen, J. P. T. 1999. Phylogenetic analysis of 16S rRNA genes and PCR analysis of the necl gene from Streptomyces spp. causing common scab, pitted scab, and netted scab in Finland. Phytopathology 89:462-469.

18. Lambert, D. H., and Loria, R. 1989. Streptomyces scabies sp. nov; nom rev. Int. J. Syst Bacteriol. 39:387-392.

19. Lambert, D. H., and Loria, R. 1989. Streptomyces acidiscabies sp. nov. Int. J. Syst. Bacteriol. 39:393-396.

20. Lambert, D. H., Reeves, A. F., Goth, R. W., Grounds, G. S., and Giggie, E. A. 2006. Relative susceptibility of potato varieties to Streptomyces scabiei and S. acidiscabies. Am. J. Potato Res. 83:67-70.

21. Lehtonen, M. J., Rantala, H., Kreuze, J. F. Bang, H., Kuisma, L., Koski, P., Virtanen, E., Vihlman, K., and Valkonen, J. P. T. 2004. Occurrence and survival of potato scab pathogens (Streptomyces species) on tuber lesions: Quick diagnosis based on a PCR-based assay. Plant Pathol. 53:280-287.

22. Loria, R., Bukhalid, R. A., Fry, B. A., and King, R. R. 1997. Plant pathogenicity in the genus Streptomyces. Plant Dis. 81:836-846.

23. Miyajima, K., Tanaka, F., Takeuchi, T., and Kuninaga, S. 1998. Streptomyces turgidiscabies sp. nov. Int. J. Syst. Bacteriol. 48:495502.

24. Park, D. H., Kim, J. S., Kwon, S. W., Wilson, C., Yu, Y. M., Hur, J. H., and Lim, C. K. 2003. Streptomyces luridiscabiei sp. nov., Streptomyces puniciscabiei sp. nov. and Streptomyces niveiscabiei sp. nov., which cause potato common scab disease in Korea. Int. J. Syst. Evol. Microbiol. 53:2049-2054.

25. Park, D. H., Yu, Y. M., Kim, J. S., Cho, J. M. Hur, J. H., and Lim, C. K. 2003. Characterization of streptomycetes causing potato common scab in Korea. Plant Dis. 87:1290-1296. 
26. Pasco, C., Jouan, B., and Andrivon, D. 2005. Resistance of potato genotypes to common and netted scab-causing species of Streptomyces. Plant Pathol. 54:383-392.

27. Sambrook, J., Fritsch, F., and Maniatis, T., eds. 1982. Molecular Cloning: A Laboratory Manual. T. Maniatis, ed. 3rd ed. Cold Spring Harbor Laboratory, Cold Spring Harbor, NY.

28. Schaad, N. W., Jones, J. B., and Chun, W., eds.
2001. Laboratory Guide for the Identification of Plant Pathogenic Bacteria. American Phytopathological Society, St. Paul, MN.

29. Scholte, K., and Labruyere, R. E. 1985. Netted scab: A new name for an old disease in Europe. Potato Res. 28:443-448.

30. Takeuchi, T., Sawada, H., Tanaka, F., and Matsuda, I. 1996. Phylogenetic analysis of Streptomyces spp. causing potato scab based on 16S rRNA sequences. Int. J. Syst. Bacteriol. 46:476-479.

31. Wanner, L. A. 2004. Field isolates of Streptomyces differ in pathogenicity and virulence on radish. Plant Dis. 88:785-796.

32. Wanner, L. A. 2006. A survey of genetic variation in Streptomyces isolates causing potato common scab in the United States. Phytopathology 96:1363-1371. 